\title{
Hearings Held on Standards Revision
}

ACRL members discussed the revision of the 1959 Standards for College Libraries during the Midwinter Meeting of ALA in Chicago, January 20-25.

During its first six months the revision committee, chaired by Johnnie Givens, Austin Peay State University, Clarksville, Tennessee, has studied typologies currently being used to classify colleges and universities in the United States. Typologies developed by the Office of Education (the Federal Interagency Committee on Education), the American Council on Education, the Carnegie Commission on Higher Education, the Academy for Educational Development, and James Cass and Max Bernbaum (Selectivity Index of Colleges and Universities) have been compared by the committee. The committee intends to select the most useful typology available in order to define the college as an institution separate and distinct from the two-year college, the community college, and the university. The committee expects to select its typology on the basis of a classification of homogeneous groupings which have characteristics that are easily identified and defensible.

A background paper on typologies, prepared by James Pirie and David Perkins, a paper on elements presently found in existing standards, prepared by Herman Totten, and a review of library standards used in other countries, by David Kaser, also were discussed with the membership. Sets of these papers can be obtained by writing Beverly P. Lynch, Executive Secretary, ACRL, 50 E. Huron St., Chicago, IL 60611 . Hearings on later working papers will be held July 10 and 11 during the annual meeting of the American Library Association in New York.

\section{DOUGHERTY RESIGNS AS CRL EDITOR}

Richard M. Dougherty, editor since 1969 of College \& Research Libraries, a publication of the Association of College and Research Libraries, has asked to be relieved of the editorship effective July 1974. The Board of Directors of ACRL has accepted Dr. Dougherty's resignation with deep regret.

The search for a new editor is being conducted by the ACRL Publications Committee. Applications and recommendations should be sent to Dr. Fred Blum, CRL Editor Search Coordinator, Room 205, Mullen Library, The Catholic University of America, Washington, DC 20017.

\section{ACRL Board Action at Midwinter}

The Board of Directors of the Association of College and Research Libraries took the following actions during its two Midwinter Meetings, held in Chicago on January 21 and 24, 1974.

Unanimously voted to support the dues schedule presented by the American Association of School Librarians, which would have lowered the dues for membership in ALA and ACRL to $\$ 35$. (The proposal subsequently was not approved by the ALA Council. See story elsewhere in this issue.)

Unanimously APPROVED a resolution giving division presidents a seat on the ALA Council. (The resolution was subsequently defeated by Council.)

Agreed to support for election to ALA Council the following ACRL Board and committee members: Norman E. Tanis, H. William Axford, Russell Shank, George S. Bobinski, C. James Schmidt, and Jasper G. Schad.

ACCEPTED with deep regret the resignation ef- fective July 1974 of the editor of College $d$ Research Libraries, Richard M. Dougherty.

Approved a plan presented by Choice and $C R L$ under which the advertising for $C R L$ will be handled by the Choice office beginning with the 1974/75 fiscal year.

Approved a plan to move the Choice subscription files from ALA headquarters in Chicago to the Choice office in Middletown, Connecticut.

ACCEPTED with pleasure and on behalf of the ACRL membership an invitation from Eugene P. Kennedy, director of libraries at New York University, to all ACRL members to attend a reception at the Bobst Library at New York University on Wednesday, July 10, 1974, during the ALA Annual Conference.

VOTED to endorse the statement on "Security of Employment in Libraries" (American Libraries, December 1973, p.678-79) as amended and to endorse the statement on "ALA Equal Employment Opportunity Pol- 